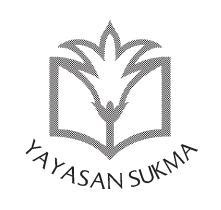

SUKMA: JURNAL PENDIDIKAN

ISSN: 2548-5105 (p), 9590 (e)

Volume 1 Issue 2, Jul-Dec 2017, hlm. 281-300

https://jurnalsukma.org/index.php/sukma/article/view/01203

\title{
RELATIONSHIP BETWEEN TEACHER PROFESSIONAL COMPETENCES AND TEACHER WORK-AUTONOMY
}

\section{Fachrurrazi}

Sekolah Sukma Bangsa Bireuen, Aceh, Indonesia email: mdfachrurrazi@yahoo.com

\section{Abstract}

The article discusses the relationship between teacher professional competences and teacher work-autonomy at Sukma Bangsa Schools in Aceh, Indonesia. The study investigated differences in teacher professional competences and teacher work-autonomy in terms of gender, school location, classroom teacher/subject teacher, grade level and teaching experiences. The study indicated that most teachers of Sekolah Sukma Bangsa in Aceh were at moderate degree of teacher professional competences and most of the teachers attained a moderate degree of work-autonomy. The study showed 
that when the level of teacher work-autonomy increased, the level of teacher professional competences escalated; while lower level of teacher autonomy was associated with lower level of teacher professional competences. Furthermore, the study revealed that a degree to which teachers perceived work-autonomy and a degree to which teachers perceived professional competences were diverse based on gender, classroom/ subject teacher, experience, level of school and location of school, even though the differences were not statistically significant.

[Artikel ini mendiskusikan hubungan antara kompetensi professional guru dan otonomi-kerja guru. Tujuan dari riset ini adalah untuk menginvestigasi hubungan antara kompetensi professional guru dan otonomikerja guru, serta perbedaan kompetensi professional guru dan perbedaan otonomi kerja guru berdasarkan gender, lokasi sekolah, guru kelas/guru pelajaran, level kelas atau pengalaman mengajar. Hasil riset juga mengindikasi bahwa ada korelasi yang positif dan moderat antara otonomi-kerja guru dan kompetensi profesional guru. Hasil riset mengindikasi bahwa ketika level otonomi-kerja guru meningkat, level kompetensi profesional guru juga naik, dan rendahnya tingkatan otonomi-kerja guru dihubungkan dengan rendahnya kompetensi professional guru. Hasil riset juga mengindikasikan level otonomi-kerja dan level kompetensi professional guru bervariasi berdasarkan gender, lokasi sekolah, guru kelas/guru pelajaran, level kelas dan pengalaman mengajar, walaupun perbedaannya tidak signifikan secara statistik.]

Keywords: teacher work-autonomy, teacher professional competences, teaching competency 


\section{On Teacher's Autonomy}

Maulipaksi (2016) stated that only teachers from 7 provinces of 35 provinces passed the minimum score of 55 for the Teacher Competence Test in 2015 in Indonesia. The Indonesian test of teacher competence measured teacher competence for only two constructs: professional competence and pedagogical competence. However, Law No.14 of 2005 stated that teacher competence in Indonesia includes pedagogical, social, professional and personality competences. The result indicated that Indonesian teachers failed to pass the minimum grade of teacher competence test even though it only measured two constructs of the competences. If teachers were tested for all competences, the success rates might decrease significantly. To a significant extent the score was a valid indicator of teacher quality in Indonesia. Napitupulu (2015) stated that most of the 1.6 million teachers who participated in the teacher competence test had scores below 55 out of 100 . There were only 200.000 teachers had 60 or higher. Moreover, Hurriyati (2015) stated that the average score of pedagogical competence in the teacher competence test 2015 was $56.69 \%$. The facts clearly suggest that teachers in Indonesia had difficulty in acquiring the fundamental competences as required by the Law.

Certainly, teacher competences are among the most valuable part of educational assets. It can be said as indicating the quality of education in a country. Hypothetically, a high level of teacher competence indicates a superior condition of education, while a low level of teacher competence is associated with an inferior quality of education. The teacher competence concept varies from nation to nation, but the basic construct of it is always similar. Teacher competences usually deal with pedagogical, personal and professional skills (World Bank, 2010). Pedagogical skill deals with an ability to understand students, constructing and accomplishing the studying process, study evaluation and development of students' individual potential; personal skill originates from a kind, calm, wise and honourable personal- 


\section{Fachrurrazi}

ity as model for students; and professional skill is an ability to master subject knowledge from the curriculum together with the structure and methodology of the knowledge. These fundamental constructs of teacher pedagogical, personal, and professional competences are developed into the concept of teacher professional competences.

Teacher professional competence is a theoretical concept that is based on a broad view of teacher professional roles in school and society as a whole. A paradigm considers a teacher as a researcher as well as a reflective practitioner (Niemi, 2012). Teacher's tasks as a researcher and a reflective practitioner, as stated in the European draft as "Common European Principles for Teacher Competences and Qualification", are that teachers have to: (a) work with others (learners and teachers); (b) work with knowledge, technology and information; and (c) work with and in society (Caena, 2011).

First, to work with others means a teacher should be able to work with students and society as their main clients. He or she should be able to stimulate the students to work with their top performances while he or she also wants to help society to mature and transform students into full citizens who are ready to contribute and prepare to become active members of society. Moreover, a teacher also needs to work with his/her teacher colleagues in order to boost learning and teaching skills. In working with all of the colleagues, a teacher needs to understand the concept of human growth and development (Niemi, 2012).

Second, to work with knowledge means a teacher stands in the position of mastering all kinds of knowledge. A teacher should be ready to work with various kinds of knowledge (Niemi, 2012), as he or she will be consulted by numerous groups of people, with of course numerous kinds of knowledge. Just like a parent who should be ready to be consulted by their ultra-curious children at home with numerous unexpected or irrational questions. As parents should be ready to be a walking encyclopaedia, teachers should be as well. But are the teachers ready for this? 
It is 'yes' when the teacher training centre has equipped them to do so. Furthermore, teachers should be ready in applying all the technology to help the clients in developing themselves, since technology nowadays is a kind of diminution where all nutritious, advanced and latest knowledge can be easily found and learned.

Third, to work with and in society means a teacher should be able to build values in the society, to respect every citizen and contribute actively in building the society. Teacher skills should enable them to encourage the notion of multiculturalism in their society, that they equally serve all members of their society, not exclusively just specific group of people. So the ideas of racism, Islamophobia, cultural exclusivism should not take place within modern citizenship. Therefore, teachers should be able to actively cooperate with anyone who cares and responds to every idea in order to work together in building a better society.

In the notion of professionalism, there are conditions to be accomplished by an individual in order to be called as a professional worker. The main prerequisite of professionalism is that every employee has a sense of autonomy while doing his responsibility (Muhson, 2004). Teacher has been considered as a professional employee due to his or her suitability in fulfilling all the standards of professional job. Teacher has to fulfil all principles of professional employees (Muhson, 2004). More detailed, first, teachers have an exclusive expertise which is different from other professions; second, teacher's work is considered as a fulltime job; third, teachers have standard theories in practicing their work; four, teacher is a profession that has contribution in building the society; five, teachers own diagnostic skills that allow them to apply very applicative theories based on the need of the clients (students); six, teacher applied the work based on common teacher ethics both in the school and society; seven, teacher has exclusive clients; and eight, teacher has established a special organization of profession. Within the organization, teachers help each other in boosting and developing the quality of their professional capacity. 
The most essential condition of teacher professionalism is that teachers have autonomy in fulfilling the job obligation (Blasé \& Kirby, 2009 as cited by Strong, 2012). Without autonomy, teacher would be under obligation to others and this could lead to independency and lack of creativity and authority. In years, organizational theories argue that in building organizational efficiency, employee professional autonomy must be enhanced by allowing staff to have power of decision making and to have sense of freedom in thinking and acting (Luthans, 1992 as cited by Friedman, 1999). Decentralized organization always considered to be better than centralized organization. Studies indicate that organization in which decision making is formulated only in the managerial circumstances is less efficient than an organization that decentralizes its decision making process (Friedman, 1999). Thus, recently, public organization as well as private organization and business organization have increased their staff professional autonomy in the spirit of decentralized power to their local units.

As well as other organizations, schools also tend to have this kind of inefficient experiences. Schools used to limit their decision making processes within the administrators' circumstance. Schools used to abandon teachers behind, to supply them with "ready to execute" decisions. As a consequence, numerous school decisions cannot be utilized in school environment due to its inappropriateness; even worse, the decisions are contraproductive to educational objectives. With the spirit of bringing education to a more well-organized condition, many new curricula are endorsed. Unfortunately, those curricula still tend to omit teacher role in decision making and decrease teacher autonomy. As the result, those acts increase the disappointment toward curriculum reforms (Tamir, 1986 as cited by Friedman, 1999). In daily schooling practices, teachers still tend to be put at the back or to be instructed, without sufficient authority to manage their teaching affairs independently.

On the other hand, there are factors related to teacher autonomy in the classroom as well as at school in general. Several studies suggest that teachers' happiness in working contributes 
to the positive impacts at schools, their resilience, and working performance in the classrooms (cited in Strong, 2012). One determinant factor that affects their happiness is the availability of autonomy, a desired condition in their work place (Blase \& Kirby, 2009). By increasing teachers' autonomy, teacher will be passionately working and teacher will work creatively and independently (Blase \& Kirby, 2009). Autonomy is also required as teachers' role is exceptional as they are the key players in building and maintaining relations with students and parents (Strong, 2012) and they are irreplaceable, more than books, school buildings, or curricula.

Autonomy is also related to the development of teacher professional competences. It is as freedom and authority facilitate teachers to learn and act dynamically, both to develop and implement their knowledge and different concept of teaching. So, conversely, decreasing teacher autonomy will potentially raise pressures on teachers, due to the limited area of authority and inadequate area of working. Teachers with high level of autonomy tend to have higher level of competence. One perceptible reason is that with autonomy, teachers become accustomed to conduct professional judgments in their instructional activities in the classrooms, as well as to make decisions in many contexts and situations (Lamb \& Reinders, 2008).

Autonomy is inevitably needed by teachers as they are the main actors of education in the classrooms beside the students. Teachers need to act and carry out responsibilities regarding curriculum, pedagogy, assessment, students' behaviour, classroom environment and professional development (O'Hara, 2006 as cited by Strong, 2012). With the freedom they have, teachers can act not only independently but also creatively. How a composer works might to a certain extent clarify what it means for teachers. A composer with the freedom he has is more able to improvise during the creative process, to produce a better symphony.

However, some experts suggest that it is necessary to limit teacher autonomy as school administrators and policy makers 


\section{Fachrurrazi}

must consider local and national expectations (Bjork, 2004). They believe that to restrain teacher autonomy is unavoidable since national administrator is the real possessor of education. So, schools have to accommodate national objectives as they are represented and governed by the state bureaucrats. Teachers' aspirations, therefore, are implemented only in the minor area of education since they are not the real owner of education.

Nowadays, the discourse on enforcing teacher autonomy is now considered as an alternative for the dilemma and paradox in education. That is why that now schooling system is recommended to be decentralized, the distribution of power from top administrators to the teachers. There are efforts to gradually reduce top-down policy in schools, such as through providing schools the opportunities to initiate, suggest and contribute in decision making processes. That is why teachers in recent years have a very active role in school management (Friedman, 1999). They have different tasks indicating their greater involvements, such as budgeting, financing and managing the provision of school resources (Friedman, 1999). So, in order to boost school achievement in different aspects, teacher should be strengthen and its implementation should be nourished in classrooms and schools.

The importance of teacher autonomy has enthused researchers to develop methods to measure teacher autonomy, included psychometric instruments. There are instruments known widely, such as Sense of Teacher Work Autonomy (SAS; Charters, 1976), Teaching Autonomy Scale (TAS; Pearson \& Hall, 1993), Self-Empowerment Index (SEI; Wilson, 1993) and Teacher Work-Autonomy Scale (TWA; Friedman, 1999) (Strong (2012)). Each instrument has its own strength and weakness as they measures emphasizes different aspects of teacher autonomy. There are inclusiveness, adaptability, completeness (of constructs), applicability, and ecological validity of the instruments (Strong, 2012).

Based on the reliability of each instrument there have been 
some suggestions. Friedman briefly stated that APA is developed to empower teacher against external interferences, pressure and control in the classrooms; TAS is designed to empower teachers to control work environment in the classrooms; SEI is developed to strengthen teachers in self-empowerment in their classrooms; and TWA is designed to strengthen teachers to work independently, initiate new activities both in the classroom area in the school. All of the instruments are intended to provide teachers the opportunities to empower themselves in both inside and outside classroom. With their autonomy, modern teachers have sufficient power in budgeting, designing and developing curricula, making decision at schools, an administering different activities (Strong, 2012).

Among those instruments, Strong personally claimed that Teacher Work-Autonomy (TWA) is the most compelling, promising and reliable instruments to be applied in researching teacher autonomy qualitatively, as it is up to date in terms of its content and is used internationally. It measures both the classroom and school dimensions (Strong, 2012). Teacher Work-Autonomy (TWA) instrument was developed in Israel by Friedman (1999) with the help of experienced teachers, senior principals and local administrators. Furthermore, the psychometric research of TWA also has been completed with the sample of US teachers by Strong (2012).

\section{Teacher Professional Competences at Sekolah Sukma Bangsa}

The study showed most teachers of Sekolah Sukma Bangsa were at a moderate level of teacher professional competences. It measured the level of existing perceived professional competences. Teachers rated diversity on pupils as the factor with the highest degree of autonomy. This item measured how teachers decide on classroom work procedure and classroom basic assessments procedure. Elmore (1987) stated that teachers were very confident in their ability related to classroom work procedures. This study supports the previous study by claiming that Sekolah 
Sukma Bangsa teachers' highest professionalism was in the skill of deciding classroom procedure and basic assessment instruction. As well as other teachers, Sekolah Sukma Bangsa teachers also value the basic skill of giving classroom instruction and assessment instruction as their greatest asset in the profession. The percentage of teacher professional competences is $17.1 \%$ (low level competence), 64.3\% (medium level competence), and $18.6 \%$ (high level competence).

The degree to which teacher perceived professional competences was diverse based on gender, classroom/subject teacher, experience, school level and school location even though the differences were not statistically significant. The significant difference only emerged in the factor of pupil diversity for classroom/subject teacher, the factor of pupil diversity and and the factor of cooperation at school level and the factor of cooperation for teaching experience. The significant differences in those variables may rise because of teaching practice variations. Teachers who teach as a subject teacher may have different competences from the one who teach as classroom teacher. As subject teacher may focus in acquiring more understanding of his/her own subject, a classroom teacher have to struggle with several subjects to be taught. Furthermore, teachers who teach in senior high school may have different competences from the one teaching in junior high school and elementary school. As senior high school teacher may practice and discuss advance knowledge day by day with her/his talented students, elementary teachers can only practice and discuss basic knowledge with her/his junior students. Moreover, teachers who have spent more time in teaching students may have advanced and better knowledge of pedagogy, personal and professional competences compared to those who spend less time in teaching.

However, several important distinctions emerge based on those independent variables. This finding confirms prior research that secondary school provide teachers with more tasks related to school operation as team teaching and decision making (Strong, 2012). Such additional tasks take secondary school teacher to the 
next level of professional competences.

This study is dissimilar to previous researches by presenting the non-significant difference in professional competences between elementary and secondary school teachers. Sekolah Sukma Bangsa teachers have equal professional competences regardless their level of teaching. Extra job description as decision making and school wide operation also possess by all teacher level in elementary and secondary school. Sekolah Sukma Bangsa tends to work collaboratively regarding school wide operation aspect and decisional making aspect. All teachers will gather in one meeting room when it is time to making decision regarding all school operation. So, there is no differences in decision making ability for Sekolah Sukma Bangsa teachers.

Unexpectedly, the differences based on gender, classroom/ subject teacher mainly emerged in the factor of pupil diversity. This factor assesses teacher professional competences on preparing students for future, promoting culture, gender and students' individual growth and interaction. Teacher competences in promoting social participation for students vary due to teacher personal social life. Gender may affect this skill of teacher due to their participation in social activities. Niemi (2012) claimed that knowledge can be gained not only by learning individually, but also through active participation in society. So, teachers with various participations in community may have better competence to their counterparts who only gain knowledge by personal studying. Moreover, he/she has a better solution to students' problem.

Another difference in degree of professional competences based on school level, teachers' experiences and school location emerged in the cooperation factor. This factor measures working, managing, evaluating, mastering academic and administrative content. School administrators may offer teachers the ability to start taking part in administrative job in school. Administrator as the owner of authority over finance, curriculum and professional development (Grawlik, 2005) may transfer some of the power to 


\section{Fachrurrazi}

teachers so that they can learn how to deal with the job to increase their competences in administrative expertise. Why this difference was not significant in Sekolah Sukma Bangsa teachers is due to their cooperation activities from all teachers from all school level. Novice teachers and expert teachers work together and help each other to raise their level of competences. All teachers of Sekolah Sukma Bangsa have equal cooperation skills. Overall, all teachers of Sekolah Sukma Bangsa have the same opportunity to gain the highest degree of professional competences regardless of their gender, classroom/subject teachers, experience, level of teaching or location of school.

\section{Work-autonomy of Sekolah Sukma Bangsa Teachers}

The findings from this study show that most teachers of Sekolah Sukma Bangsa attained a moderate degree of autonomy. Teacher work-autonomy is evaluated through the degree of teachers' power to work independently, to initiate new activity and to change work procedure and to adapt it (Friedman, 1999). The sample teachers rated teaching and assessment as the factors with the highest degree of autonomy and rated the personal development factor as the lowest degree of autonomy. Teaching and assessment, including teachers' ability to choose the instructions and curriculum, together with teachers' participation in the school area decision making are teachers' desired workplace conditions (Strong, 2012). The teacher assessment item measured how teachers decide on classroom work procedures and classroom basic assessment procedures while the professional development item evaluated teacher capacity building. Autonomy in the classroom had been the mostly highly rated item from the latest research until now. Blasé and Kirby (2009) stated that teaching pedagogy or individual classroom operation is the most common area in which teachers perceive having autonomy. The percentage of teacher work-autonomy degree is $14.3 \%$ in low level, $68.6 \%$ in medium level, and $14.3 \%$ in high level.

The degree to which teacher perceived work-autonomy 
was divergent based on gender, classroom/subject teacher, experience, level of school and location of school, and although there were differences in this study, they were not statistically significant. The significant difference only emerged in the teaching and assessment factor of school location. It means that teachers from the three schools acquired different levels of work-autonomy, especially in the factor of teaching and assessment. Variation in leadership in every school location may lead to significant differences in teaching and assessment. Furthermore, trust from the leader of the organization will increase the level of autonomy for workers. Thus, it can be concluded that leadership and trust from the leader may direct a significant difference in teacher workautonomy.

However, several important distinctions emerged based on these independent variables. This finding is dissimilar to a prior research finding which states that teacher autonomy for elementary and secondary levels is contrasted significantly (Strong, 2012). The differences may rise due to variation in sample characteristics, methodology and culture. However, this research claims that the degree of teacher autonomy is not different based on the level of the school. Every teacher can possess a high degree of teacher autonomy regardless of their gender, experience, the level of school and location of the school. The teachers of Sekolah Sukma Bangsa are able to apply all the expertise they have both in the classroom and in the wide-school environment. Only when teacher autonomy in teachers' activities is not reduced by external forces are teachers able to do the work independently.

Unpredictably, the non-significant differences based on gender, classroom/subject teacher, and school level mainly emerged in the teaching and assessment factor. As the main field in which teachers perceive their autonomy (Blasé and Kirby, 2009), the teaching and assessment also has the potential to generate significant differences in degrees of autonomy. This phenomenon maybe influenced by the teacher-student relationship. Teachers have a stronger relationship with students and parents (Crawford, 2001). Teachers with stronger relationships 
with students may increase their level of autonomy in teaching and assessment.

Another surprising fact is that there was no significant differences based on school level in this study. School level tends to influence the degree of teacher autonomy. Elementary school teachers tend to have more bounded curriculum instruction than those in secondary school (Rudolph, 2006). However, this study challenges the research and claims that there was no significant differences regarding the school level. Sekolah Sukma Bangsa teachers seem to have a similar opportunity to reach equal levels of autonomy regardless of their level of teaching. It means that teachers from elementary school have the same opportunity as the secondary school teachers to have a high degree of autonomy. We may assume that they have dissimilar opportunity in applying the instruction in the classroom and school but this study shows that that difference does not influences the level of autonomy they have.

The differences in degree of autonomy based on teacher experiences emerged in the school mode of operation factor. This factor measures the power of teachers in making decisions in school wide area activities such as budgeting and curriculum. The power of decision making is an important characteristic of teacher autonomy (Crawford, 2001). Teachers with more experiences and higher degree of decision making expertise are associated with greater level of autonomy. This study however, claims that there was no significant difference in the degree of teachers autonomy based on teacher experiences. Sekolah Sukma Bangsa teachers equally possess the power of making decisions regardless of their experiences. Novice teachers as well as expert teachers have the same degree of autonomy in the decision making process. Decision making autonomy in instructions and budgeting contribute to the level of professionalism that Sekolah Sukma Bangsa teachers have. Overall, every teacher in Sekolah Sukma Bangsa has the same opportunity to possess the high degree of autonomy regardless of their gender, class/subject teacher, experience, level of teaching or location of school. 
Relationship between Teacher Competences and Teacher Work-Autonomy Relationship between Teacher Work-autonomy and Teacher Professional Competences

This study claim a moderate (Evans, 1996) and positive correlation between teacher work-autonomy and TPC. The direction of correlation was positive and there was evidence found of correlation between Teacher work-autonomy and Teacher professional competences. The result indicates that when level of teacher autonomy increase, the level of teacher professional competences escalated, while lower level of teacher autonomy is associated with lower level of teacher professional compe-

\begin{tabular}{l|l|l|l}
\hline \multicolumn{2}{c|}{} & $\begin{array}{l}\text { Teacher pro- } \\
\text { fe s s i o n a l } \\
\text { competences }\end{array}$ & $\begin{array}{l}\text { T e a c h e r } \\
\text { w o r k - } \\
\text { autonomy }\end{array}$ \\
\hline \multirow{2}{*}{$\begin{array}{l}\text { Teacher pro- } \\
\text { f e s s i o n a } \\
\text { competences }\end{array}$} & Pearson Correlation & 1 & \\
\cline { 2 - 4 } & Sig. (2-tailed) & & \\
\cline { 2 - 4 } $\begin{array}{l}\text { T e a c h e r } \\
\text { work-auton- } \\
\text { omy }\end{array}$ & Pearson Correlation & 70 & 1 \\
\cline { 2 - 4 } & Sig. (2-tailed) & .000 & \\
\cline { 2 - 4 } & $\mathrm{N}$ & 69 & 69 \\
\hline \hline
\end{tabular}

** Correlation is significant at the 0.01 level (2-tailed).

\section{Figure 1: Relationship between teacher professional competences and teacher work-autonomy}

tences. Supplying teacher with high level of work autonomy is one obvious way to upsurge teacher professional competences. The result confirm many researches that claimed the most essential conditions of teacher professionalism is that teachers have autonomy in fulfilling the job obligation (Blasé \& Kirby, 2009 as cited by Strong, 2012). We may simply conclude that as degree of autonomy increased, degree of competences increased. On the opposite, when the score of autonomy decreased the score of professional competences is decreased. 
TWA has the strongest inter-relationship in instruction component. The correlation supports the notion that teaching profession appreciates skill of pedagogy (instruction) very much. This view is supported by Niemi (2010). The instruction dimen-

\begin{tabular}{|c|c|c|c|c|c|c|}
\hline & & 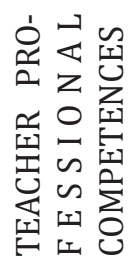 & 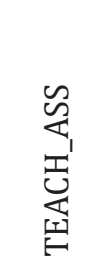 & 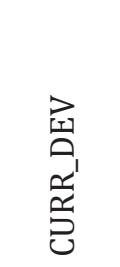 & $\begin{array}{l}0 \\
\sum_{1}^{0} \\
\text { İ } \\
\text { 另 }\end{array}$ & 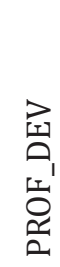 \\
\hline \multirow{3}{*}{$\begin{array}{l}\text { TEACHERS' } \\
\text { P R O F E S - } \\
\text { S I O N A L } \\
\text { C O M P E - } \\
\text { TENCES }\end{array}$} & $\begin{array}{l}\text { P e a r s o n } \\
\text { Correlation }\end{array}$ & 1 & & & & \\
\hline & Sig. (2-tailed) & & & & & \\
\hline & $\mathrm{N}$ & 70 & & & & \\
\hline \multirow{3}{*}{$\begin{array}{l}\text { T E A C H I N G } \\
\text { AND ASSESS- } \\
\text { MENT }\end{array}$} & $\begin{array}{l}\text { P e a r s o n } \\
\text { Correlation }\end{array}$ & .212 & 1 & & & \\
\hline & Sig. (2-tailed) & .080 & & & & \\
\hline & $\mathrm{N}$ & 69 & 69 & & & \\
\hline \multirow{3}{*}{$\begin{array}{l}\mathrm{C} \quad \mathrm{U} \quad \mathrm{R}- \\
\mathrm{R} \text { I C U L U M } \\
\text { DEVE L O P - } \\
\text { MENT }\end{array}$} & $\begin{array}{l}\text { P e a r s o n } \\
\text { Correlation }\end{array}$ & $.568^{* *}$ & $.291 *$ & 1 & & \\
\hline & Sig. (2-tailed) & .000 & .015 & & & \\
\hline & $\mathrm{N}$ & 69 & 69 & 69 & & \\
\hline \multirow{3}{*}{$\begin{array}{l}\text { S C H O O L } \\
\text { MODE OF } \\
\text { OPERATING }\end{array}$} & $\begin{array}{l}\text { P e a r s o n } \\
\text { Correlation }\end{array}$ & $.366^{* *}$ & .135 & $.442^{* *}$ & 1 & \\
\hline & Sig. (2-tailed) & .002 & .269 & .000 & & \\
\hline & $\mathrm{N}$ & 69 & 69 & 69 & 69 & \\
\hline \multirow{3}{*}{$\begin{array}{l}\text { P R O F E S - } \\
\text { S I O N A L } \\
\text { DEVELOP - } \\
\text { MENT }\end{array}$} & $\begin{array}{l}\text { P e a r s o n } \\
\text { Correlation }\end{array}$ & $.374^{* *}$ & .174 & $.471^{* *}$ & $.506^{* *}$ & 1 \\
\hline & Sig. (2-tailed) & .002 & .152 & .000 & .000 & \\
\hline & $\mathrm{N}$ & 69 & 69 & 69 & 69 & 69 \\
\hline
\end{tabular}

Figure 2: Correlation of teacher professional competences and dimensions of teacher work-autonomy 
sion is the most powerful variable to cause variation in other professional competences. Moreover, TPC has the strongest inter-correlation in school mode operating component. The correlation supports the notion that teachers need this school mode of operating autonomy very significantly. This view is supported by Niemi (2010). The school mode of operating dimension is the most powerful variable to cause variation in other teacher work autonomy variables.

There were strong correlations between teacher work autonomy and teacher professional competences. Teacher work autonomy and teacher professional competences related to each other in very dynamic ways. The strongest correlation existed between teacher work autonomy and teacher professional competences in the task that require professional competences. These tasks are part of professional development and school mode operating. Its means the more professional learning activity achieved, the more professional development autonomy and school mode operating autonomy are acquired and vice versa. The highest relationship existed between teacher work autonomy and teacher professional competences. It means the more professional learning acquired the more curriculum development autonomy will be received.

Overall, this study reveals the teacher work-autonomy and teacher professional competences score of Sekolah Sukma Bangsa teachers, and shows a significant relationship between them. The research also points out some potential differences based on gender, location, subject/classroom teacher, levels and experience. It must be borne in mind that this research was only conducted on a small group of teachers over a short period of time. Further research is hence needed over a long period of time and with a large number of teachers before generalized conclusions can be drawn.

\section{Conclusion}

Most teachers of Sekolah Sukma Bangsa occupied a moderate 
degree of teacher professional competence (64.3\%), while 18.6 $\%$ of teachers demonstrated a high degree of teacher professional competence, and the remaining $17.1 \%$ of teachers had a low degree of teacher professional competence. Furthermore, most teachers of Sekolah Sukma Bangsa attained a moderate degree of autonomy (68.6\%) while $14.3 \%$ of teachers gained a high degree of autonomy and the remaining $14.3 \%$ of teacher had a low degree of autonomy. There is a significant and positive relationship between teachers' autonomy and teacher professional competences. Although there are some difficulties in maintaining teacher work-autonomy and teacher professional competences, both of them are significant factors and fundamental resources in building the educational organization. Government and school administrators should provide enough room for teachers' autonomy and encourage teachers to boost themselves in gaining more autonomy. If this is done, teachers will have professional expertise and be ready to bring the students to the next step of experiencing the world of education. This study shows the variation of the degree of teacher work-autonomy and the degree of teacher professional competences of Sekolah Sukma Bangsa teachers in Aceh. The score of teacher work-autonomy and teacher professional competences at Sekolah Sukma Bangsa in Aceh shows a positive and moderate correlation. The result indicates that when the level of teacher autonomy increases, the level of teacher professional competences escalates, and a lower level of teacher autonomy is associated with a lower level of teacher professional competences. For Sekolah Sukma Bangsa teachers, equipping them with a high degree of work autonomy is one obvious way to upsurge their professional competences. 


\section{BIBLIOGRAPHY}

Benson, P. (2001). Teaching and Researching Autonomy in Language Learning. London: Longman.

Bjork, C. (2004). Decentralisation in education, institutional culture and teacher autonomy in Indonesia. International Review of Education, 50, 245-262. Retrieved May 20, 2016, from https:// www.jstor.org/stable/4151598.

Blase, J., \& Kirby, P. C. (2009). Bringing out the best in teachers: What effective principals do.Thousand Oaks, CA: Corwin Press.

Caena, F. (2011). Literature review Teachers' core competences: Requirements and development. Education and Training 2020 Thematic Working Group 'Professional Development of Teachers'.

Cleophas, T. J., \& Zwinderman, A. H. (2016). SPSS for Starters and 2nd Levelers (Second ed.). Retrieved June 15, 2016, from http://www.springerlink.com/openurl.asp?id=d oi:10.1007/978-3-319-20600-4

Crawford, J. R. (2001). Teacher autonomy and accountability in charter schools. Education and Urban Society, 33, 186-200.

Elmore, R. F. (1987). Reform and the culture of authority in schools. Educational Administration Quarterly, 23, 60-78.

Evans, J. D. (1996). Straightforward statistics for the behavioral sciences. Pacific Grove, CA: Brooks/Cole Publishing 79

Fleming, D. (1998). Autonomy and Agency in Curriculum DecisionMaking: A Study of Instructors in a Canadian Adult Settlement ESL Program. TESL Canada Journal, 16(1). http://dx.doi. org/10.18806/tesl.v16i1.708

Friedman, I. A. (1999). Teacher-perceived work autonomy: The concept and its measurement. Educational and Psychological Measurement, 59, 58-76. Retrieved May 18, 2016, from http:// epm.sagepub.com

Furlong, J., Barton, L., Miles, S., Whiting, C., \& Whitty, G. (2000). Teacher education in transition Re-forming professionalism? Open University Press. 
$\overline{\text { Gravetter, J. F., \& Wallnau, B. L. (2013). Statistics for the Behavioral }}$ Sciences. USA: Wadsworth.

Guarino, C. M., Santibanez, L., \& Daley, G. A. (2006). Teacher recruitment and retention: A review of recent empirical literature. Review of Educational Research, 76, 173-208.

Herianto, E. (2004). Otonomi Guru pada Era Kurikulum Berbasis Kompetensi.JURNAL ILMU PENDIDIKAN, 11. Retrieved August, 2016.

Horng, E. L. (2009). Teacher tradeoffs: Disentangling teachers' preferences for working conditions and student demographics. Administrative Educational Research Journal, 46, 690-717.

Hoyle, E. (1970). Planned organisational change in education. Research in Education. Retrieved December, 2016, from http://search.proquest.com/

Hurriyati, R. (2016). Kualitas Guru Kita. Retrieved December 15, 2016 , from http://www.pikiran-rakyat.com/ opini/2016/05/04/kualitas-guru-kita-368286

Ibtisam, F. (2016). 10 Jurusan Kuliah Paling Diincar (Sehingga Paling Kompetitif) di SBMPTN. Retrieved 2016, from http:// www.youthmanual.com/

Indonesia. (2005). UNDANG-UNDANG REPUBLIK INDONESIA NOMOR 14 TAHUN 2005 TENTANG GURU DAN DOSEN.

Ingersoll, R. M. (2001). Teacher turnover and teacher shortages: An organizational analysis. American Educational Research Journal, 38, 499-534. 80 